\title{
A Comparative Analysis of Religiosity among Students of University and Madrassa System in Punjab, Pakistan
}

\author{
${ }^{a}$ Muhammad Shahzad Ashfaq \\ ${ }^{a}$ PhD Scholar, Department of Education, University of Sargodha, Pakistan \\ Email: shahzadashfaq24@gmail.com
}

\begin{tabular}{l}
\hline ARTICLE DETAILS \\
\hline History: \\
Accepted 26 October 2021 \\
Available Online December 2021
\end{tabular}

Keywords:

Comparison, Religiosity,

University students, Madrassa

students, Punjab, Pakistan

\section{JEL Classification:}

I21, I23, I28, I29

DOI: $10.47067 /$ real.v4i4.201

\begin{abstract}
The study aimed to analyze the religiosity among students of universities and the madrassas system. It also compares the religiosity of university and madrassa students. The researchers chose a mixedmethod research design. The study sample selects through a multi-stage sampling technique. The study participants were 896, including 640 students (320 from universities and 320 from madrassas) and 256 teachers/heads of the departments/institutions. The study used two research instruments to collect data from respondents. To measure the level of student's religious belief (religiosity) self-developed questionnaire was employed. By semi-structured interview schedule, views of teachers and heads of institutions were composed. The data were analyzed using SPSS version 21, means level and Independent Samples T-Test (t-test). The study results show that both university and madrassa students maintain a high level of religiosity. Comparing students by institution displays that there were significant differences in religiosity between them. Madrassa students have a high level of religiosity, while university students are at a moderate level. The study suggests large-scale, in-depth research, including public and private universities and madrassas throughout Punjab.
\end{abstract}

(C) 2021 The authors. Published by SPCRD Global Publishing. This is an open access article under the Creative Commons AttributionNonCommercial 4.0

Corresponding author's email address: shahzadashfaq24@gmail.com

\section{Introduction}

Religion plays an important part in the life of people to shape their behaviour and attitudes (Zamani-Farahani and Musa, 2012; Ullah and Hameed, 2021). It is important that religion influence on moral and ethical values of people through the provision of Islamic principles and religious philosophies. Several times in the life of people they follow Islamic values and act on these principles of religion (Niazi, Ghani, \& Aziz, 2019; Ullah and Hameed, 2021). Religion Islam has the most popular or second-largest religion in the modern world it has also fifty Muslim countries in the world. Moreover, sixty-two percent of the Muslim population lives in the Asia region, and people heart-to-heart follow the religion of Islam. Therefore, with more than two hundred million population of people, Pakistan stands as the third-largest Muslim country. The majority statistics of the Muslim population in Pakistan is 
approximately 96\% which is equal to eleven percent of the Muslim world (Niazi et al., 2019; Ullah and Hameed, 2021).

The concept of religiosity has long been known in the fields of education and philosophy. During recent years, a going interest has been witnessed in the concept of religiosity among the scholars and practitioners in the field of positive psychology (Berkowitz \& Bier, 2004, Damon \& Lerner, 2008, Lapsley \& Narvaez, 2006, Peterson \& Seligman, 2004, Shubert, 2018). Psychological research usually focuses on the behaviour of individuals in pathological settings. However, the understanding of human interests evolved into positive psychology aimed at establishing superiority. Individual behaviour has virtues that can help communities survive but can also enhance human power (Seligman, 2002; Ahmed, 2009). Students may be exposed to many factors that increase honesty and self-esteem under healthy conditions.

According to Karl Marx, religion can offer hope of supernatural intervention to solve problems on earth. Humans try to do anything significant to help improve their current conditions. The theory of Jung Carl, (2020) declares that religion is one of the many psychological attitudes people adopt towards life. He does not confine religiosity to any specific type, but he does place its value in how much a person is willing to place any specific thing as something they value. Alshehri and Fotaki, (2019) describe religiosity as a belief in Almighty Allah with commitment and following the principles of Allah. Pratono, (2019) suggests that the background of religiosity is to influence the behaviour and attitudes of humans. Religiosity describes the practices of social and personal expressions of connections to the purity of the soul. According to Łowicki, and Zajenkowski, (2020) religiosity appears as the participation of people in social structure relates to religion and formal outward.

Religious organizations and grassroots communities often focus on the same goals and experiences to gain a stable sense of community (Erickson, 1965; Ahmed, 2009). The religious belief support role of trusted mentors, such as like-minded parents and friends, who can help cultivate positive values and beliefs as the basis for youth support (Busseri et al., 2006; Jessor et al., 1998; Ahmed, 2009). The establishment of interpersonal relationships between adults provides a framework in which young people can work and establish their status in society (Erikson, 1965, 1968; Ahmed, 2009). However, religious institutions help young people develop self-regulation skills. These institutions provide opportunities to simulate pro-social behaviour in a structured environment. They also protect young people from anti-social behaviour (Cook, 2000; Ahmed, 2009). Therefore, the religious environment encourages the development of young people's self-esteem and provides a set of beliefs (Cook, 2000).

\section{Literature Review}

The construct of religiosity is a difficult task to define (Farhan and Rofi, 2021). The notion of religiosity first comes from western traditions that reflect people's religious phenomena. The etymology of the word religiosity refers to "religious" and their roots connect with the Latin word religio. Religiosity in the conceptual point of view describes as spirituality, piety, and obedience. The aspect of religiosity devotes religious belief and religious activities in the frustrated world of people (Farhan and Rofi, 2021). The person's religiosity teaches the important values of religion and individuals to believe in the reality of ALLAH (SWT), (Olufadi, 2017; Farhan and Rofi, 2021).

The multidimensional aspect of religiosity gives the phenomena of self-satisfaction. Stark \& Glock (1965); Farhan and Rofi, (2021) stated that religiosity in a person consists of five dimensions belief in ALLAH (SWT), prayer, the experience of good or bad, intellectual religious matters, and paying 
respect to other peoples in accordance to religious education. Islam is the religion of peace and it has made in the prosperity of humans and other creatures. In Islam, there are three vital elements for every human being first, one is faith in ALLAH (SWT) as a means to act prayer, second is the imam which guides the people the system of knowledge and provides understanding to belief in ALLAH (SWT). At last the third is Ehsan the representation of the reality of ethical principles and spiritual concepts (Sahih al-Bukhari, Vol. 6, Book 6o, Number 300, Hadìth 47). Islamic religiosity plays a healthy part in the life of human beings. The system of Islam is believed to influence the moral values, positive habits, and better lifestyles of human beings. Therefore, religiosity is known to encourage people's behaviour, life satisfaction, and various dimensions of people's wellbeing. Fatima et al., (2017) explain the positive effect of religion on human life cannot be discarded because Islam refers to moral guidelines for learners. Islam is the only religion of the world that encourage their followers to compete in seeking knowledge. The students who learn Islamic religiosity tend to know Islamic teaching about the importance of religious knowledge. Being a Muslim and a follower of Islam, it is important to be an outstanding learner. Islam encourages students to study the religious norms and values of morality.

The literature on religiosity research shows that if students have interested in religious learning, they have high enthusiasm. Religion display a positive element of culture in the civilized society that diffuses the permeates of people life either they believe in religion or not (Hamza, (2010); Yahya and Saad, (2015). Johnstone, (1975); Yahya and Saad, (2015) stated that religion provides a system of practice and belief which dictates peoples to respond to a supernatural reality. The influence of religion promotes the goals of people and religion motive others to get life satisfaction. The dominant role of religion is shaping people's attitudes towards religious services. The laws of religion play a vital and ethical role to shape the lives of people according to their benefit. Faith on ALLAH (SWT) provides the reasoning, knowledge, and foundation for moral life (Yahya and Saad, 2015). Religion acts as the opening of the cognitive world for every individual. Other than that religiosity supports the individual to be committed to their religion, profession, and learning which reflect religious commitment. Religious commitment influences human behaviour and religious attitude.

Although, the religious behaviour of an individual influence his self-identity. The self-identity of a person turns into internalization and expectations offered by religion (Weaver and Angel, (2002); Yahya and Saad, (2015). According to Zuckerman, Siberman and Hall, (2013); Yahya and Saad, (2015) explain the degree of religion as encouraging the involvement of people in all facets of religiosity. Facets of religion are categorized such as supernatural belief and commitments of faith offering to lower anxieties and validate the religious belief. Religiosity is divided into two types intrinsic religiosity and extrinsic religiosity. Allport provides the basic concept of religiosities that impact empirical research (Yahya and Saad, (2015). The author Allport 1960's separated religion and commitment of a person into two types i.e. intrinsic religiosity and extrinsic religiosity. The meaning of intrinsic religiosity endows the framework for individuals to understand the terms of life. Extrinsic religiosity refers to social convention, the comfort of religion, and approach to shape a person self-service and intrinsic religiosity assumed as a person's positive relationship with religious ethics (Donahue, 1985; Yahya and Saad, 2015).

\section{Hypothesis}

$\mathrm{H}_{\mathrm{o} 1}$ : There is no significant mean difference between the religiosity of university and madrassa students. 


\section{Material and Methods}

\subsection{Research Design}

The research design explains the basic structure and guidance for conducting research. The research reflects plans that can be quantitative or qualitative (Merriam \& Tisdell, 2015). The researchers chose a mixed-method research design.

\subsection{Participants of the Study}

In the final stage of the research, 10 Bachelor of Science students $(10 \times 32=320)$ from each selected department and 10 Shahadatul Alia and Shahadatul Almiya students $(10 \times 32=320)$ from each madrassa; four university teachers from each department, including the Head of the departments (4x32 $=128)$ and four madrassa teachers, including the Head of the institute (Nazim) $(4 \times 32=128)$ were selected conveniently. In this way, the total sample of study is 896 which includes 640 students and 256 teachers/heads of the institutions.

\subsection{Research Instruments}

A self-developed questionnaire was used to gather information from respondents. At the same pattern, the semi-structured interview schedule comprising the aspects of religiosity was developed for teachers and heads of the departments.

\subsection{Questionnaire for Participants}

The student questionnaire consists of demographic information and 30 items. These items present religiosity on a 5-point Likert scale based on religiosity values (forgiveness, dutifulness, egalitarian, social support, comfort, self-esteem). At the same pattern, the semi-structured interview schedule comprising the aspects of religiosity was validated through expert opinion.

\subsection{Data Collection and Analysis}

The researcher personally visited the universities and madrassas. Before starting the data collection process, the researcher visited the sampled institutions and sought permission from the head of the institutions. The questionnaire was distributed among the students and they were briefed about the things they would have to take care of while filling in a questionnaire. During collecting the questionnaires, the researcher scrutinized them to see any kind of discrepancies therein. If there were some incomplete questionnaires, the respondents were requested to fill them again. Written interview schedules were distributed among the teachers and heads of the institutions of both the university and madrassas after getting permission and planning meeting time.

The data were analyzed using SPSS version 21, means level and Independent Samples T-Test ( $t$ test).

\section{Table 1: Level of Religiosity of University Students}

\begin{tabular}{|l|l|c|c|}
\hline S. No & Main Theme/Sub-themes & Mean Score & Level \\
\hline & Religiosity of University Students & $\mathbf{3 . 7 5}$ & Moderate \\
\hline 1 & Intrinsic Religiosity & 3.60 & Moderate \\
\hline 2 & Extrinsic Religiosity & 3.90 & Moderate \\
\hline
\end{tabular}

Table 1 represents the religiosity of university students as moderate $(M=3.75)$. Moreover, the 'intrinsic religiosity' of university students $(M=3.60)$, and 'extrinsic religiosity' are also moderate $(M=3 \cdot 90)$. 
Table 2: Level of Intrinsic Religiosity of University Students

\begin{tabular}{|c|l|c|c|}
\hline S. No & Themes/Sub-themes & Mean Score & Level \\
\hline & Intrinsic Religiosity of University Students & $\mathbf{3 . 6 0}$ & Moderate \\
\hline 1. & Forgiveness & 3.64 & Moderate \\
\hline 2. & Dutifulness & 3.68 & Moderate \\
\hline 3. & Egalitarianism & 3.49 & Moderate \\
\hline
\end{tabular}

Table 2 displays the 'intrinsic religiosity' of university students as moderate $(M=3.60)$. Similarly, the 'forgiveness' of university students $(M=3.64)$, 'dutifulness' $(M=3.68)$, and 'egalitarianism' are also moderate $(M=3 \cdot 49)$.

Table 3: Level of Extrinsic Religiosity of University Students

\begin{tabular}{|c|l|c|c|}
\hline S. No & Themes/Sub-themes & Mean Score & Level \\
\hline & Extrinsic Religiosity of University Students & $\mathbf{3 \cdot 9 0}$ & Moderate \\
\hline 1. & Social support & 3.97 & Moderate \\
\hline 2. & Comfort & 3.67 & Moderate \\
\hline 3. & Self-esteem & 4.06 & High \\
\hline
\end{tabular}

Table 3 denote the 'extrinsic religiosity' of university students as moderate $(M=3.90)$. Likewise, the 'social support' of university students $(M=3.97)$ 'comfort' $(M=3.67)$, and 'self-esteem' are high $(M=4.06)$.

Table 4: Level of Religiosity of Madrassa Students

\begin{tabular}{|c|l|c|c|}
\hline S. No & Main Theme/Sub-themes & Mean Score & Level \\
\hline & Religiosity of Madrassa Students & $\mathbf{4 \cdot 3 6}$ & High \\
\hline 1. & Intrinsic Religiosity & 4.31 & High \\
\hline 2. & Extrinsic Religiosity & 4.41 & High \\
\hline
\end{tabular}

Table 4 embodies the 'religiosity' of madrassa students as high $(M=4 \cdot 36)$. Moreover, 'intrinsic religiosity' of madrassa students $(M=4 \cdot 31)$ and 'extrinsic religiosity' are also high $(M=4 \cdot 41)$.

Table 5: Level of Intrinsic Religiosity of Madrassa Students

\begin{tabular}{|l|l|c|c|}
\hline S. No & Theme/Sub-themes & Mean Score & Level \\
\hline & Intrinsic Religiosity of Madrassa Students & $\mathbf{4 \cdot 3 1}$ & High \\
\hline 1. & Forgiveness & 4.13 & High \\
\hline 2. & Dutifulness & 4.34 & High \\
\hline 3. & Egalitarianism & 4.46 & High \\
\hline
\end{tabular}

Table 5 displays the 'intrinsic religiosity' of madrassa students as high $(M=4 \cdot 31)$. Similarly, the 'forgiveness' of madrassa students ( $M=4.13)$, 'dutifulness' $(M=4 \cdot 34)$, and 'egalitarianism' are also high $(M=4.46)$. 
Table 6: Level of Extrinsic Religiosity of Madrassa Students

\begin{tabular}{|l|l|c|c|}
\hline S. No & Theme/Sub-themes & Mean Score & Level \\
\hline & Extrinsic Religiosity of Madrassa Students & $\mathbf{4 . 4 1}$ & High \\
\hline 1. & Social support & 4.09 & High \\
\hline 2. & Comfort & 4.57 & High \\
\hline 3. & Self-esteem & 4.58 & High \\
\hline
\end{tabular}

Table 6 represents the 'extrinsic religiosity' of madrassa students as high $(M=4.41)$. Likewise, 'social support' of madrassa students (M=4.09), 'comfort' (M=4.57), and 'self-esteem' are high $(M=4 \cdot 58)$.

Table 7: Comparison of Religiosity of Students

\begin{tabular}{|l|l|c|c|c|c|c|c|}
\hline \multirow{2}{*}{ Aspect } & Group & $\mathbf{N}$ & Mean & SD & t & df & $\begin{array}{c}\text { Sig (2 - } \\
\text { tailed) }\end{array}$ \\
\cline { 1 - 8 } Religiosity & Madrassas students & 320 & 4.3640 & .27568 & \multirow{2}{*}{3.36} & 638 & .001 \\
\cline { 2 - 8 } & Universities students & 320 & 4.2807 & .34531 & \multirow{2}{*}{. } & \\
\hline
\end{tabular}

Table 7 illustrates that the mean score of religiosities of madrassas students is 4.36 with $S D .275$ and the mean score of religiosities of universities students is 4.28 with $S D .345$. The computed $t$ value for $\mathrm{df} 638$ is 3.369 . As the computed $t$-value is greater than the required table value, consequently, it may be concluded that the results of both groups are different regarding religiosity aspects. Therefore, the null hypothesis "there is no significant mean difference between the religiosity of madrassas students and universities students" was dismissed. It was inferred that the madrassas students reflect the contrast in religiosity.

\section{Findings}

\subsection{Religiosity among University Students}

The overall level of 'religiosity' among university students is moderate $(M=3.75)$. Alongside, 'intrinsic religiosity' of university students $(M=3.60)$, and 'extrinsic religiosity' are also moderate $(M=3 \cdot 90)$.

\subsection{Intrinsic Religiosity of University students}

The level of 'intrinsic religiosity' among university students is moderate $(M=3.60)$. Similarly, the 'forgiveness' of university students ( $M=3.64)$, ‘dutifulness' $(M=3.68)$, and 'egalitarianism' of university students are also moderate $(\mathrm{M}=3 \cdot 49)$.

\subsection{Extrinsic Religiosity of University students}

The level of 'extrinsic religiosity' among university students is moderate $(M=3.90)$. Likewise, the level of 'social support' $(M=3.97)$, 'comfort' $(M=3.67)$, and 'self-esteem' of university students are high $(\mathrm{M}=4.06)$.

\subsection{Religiosity among Madrassa Students}

The overall level of 'religiosity' among madrassa students is high $(M=4.36)$. Likewise, 'intrinsic religiosity' of madrassa students $(M=4 \cdot 31)$, and 'extrinsic religiosity' are also high $(M=4 \cdot 41)$. 


\subsection{Intrinsic Religiosity of Madrassa Students}

The level of 'intrinsic religiosity' among madrassa students is high ( $M=4.31)$. Similarly, the 'forgiveness' of madrassa students $(M=4.13)$, 'dutifulness' $(M=4.34)$ and 'egalitarianism' of madrassa students are also high $(\mathrm{M}=4 \cdot 46)$.

\subsection{Extrinsic Religiosity of Madrassa Students}

The level of 'extrinsic religiosity' among madrassa students is high ( $M=4.41)$. In the same way, 'social support' of madrassa students $(M=4.09)$, 'comfort' $(M=4.57)$, and 'self-esteem' of madrassa students are high $(\mathrm{M}=4 \cdot 58)$.

\subsection{Comparison of Religiosity of University and Madrassa Students}

The computed $t$-value revealed that there is a significant difference between the religiosity of madrassa and university students. It was inferred that the madrassas students reflect the contrast in religiosity.

\section{Discussion and Conclusion}

The present study aimed to analyze religiosity among university and madrassa students in Punjab, Pakistan. The comparison was made between the students of both education systems based on their religiosity. The findings of the study revealed that the level of religiosity among university students is moderate. Similarly, the level of religiosity among madrassa students is high. Berthold and Ruch, (2014) established that those participants who practice their religion regularly scored higher on the strengths scale regarding several strengths as compared to the participants who were not regular practitioners of the religion. The present study also tried to compare the religiosity of university and madrassa students. The computed t-value revealed that there is a significant difference between the religiosity of university and madrassa students. It was also inferred that the madrassa students reflect the contrast in religiosity. The study conducted by Berthold and Ruch, (2014) on the comparison of the religiosity between the practising and non-practising religious people. The findings of the present study are consistent with it.

It was concluded from the findings of the study that the level of religiosity among university students was moderate. Alongside, the madrassa students were found to have a high level of religiosity as well. The comparison of the religiosity of the university and madrassa students revealed that there is a significant difference between the religiosity of university and madrassa students. The computed $t$ value revealed that there is a significant difference between the religiosity of university and madrassa students. It was also inferred that the madrassas students reflect the contrast in religiosity. The study concludes that both systems should use joint ventures for this purpose, such as teacher training programs, an innovative teaching method, and educational seminars. In this context, universities should organize and provide teacher training programs for madrassa teachers, and religious scholars should provide services to improve the religious knowledge of university teachers.

\section{References}

Ahmed, S. (2009). Religiosity and presence of character strengths in American Muslim youth. Journal of Muslim Mental Health, 4(2), 104-123.

Alshehri, F., Kauser, S., \& Fotaki, M. (2019). Muslims' view of god as a predictor of ethical behaviour in organisations: Scale development and validation. Journal of Business Ethics, 158(4), 1009-1027.

Allport, G. W. (1960). The individual and his religion: A psychological interpretation. New York: MacMillan. 
Berkowitz, M. W., \& Bier, M. C. (2004). Research based character education. The Annals of the American Academy of Political and Social Science, 591, 72-85.

Berthold, A., \& Ruch, W. (2014). Satisfaction with life and character strengths of non-religious and religious people: It's practicing one's religion that makes the difference. Frontiers in Psychology, 5, 876.

Busseri, M. A., Rose-Krasnor, L., Willoughby, T., \& Chalmers, H. (2006). A longitudinal examination of the breadth and intensity of youth activity involvement and successful development. Developmental Psychology, 42, 1313-1326.

Buzdar, M. A. (2012). Impact of Religious Affiliations on Rational Thinking of Secondary School Students in Pakistan (Doctoral dissertation, Islamia University Bahawalpur Pakistan).

Cook, K. V. (2000). "You have to have somebody watching your back, and if that's God, then that's mighty big": The church's role in resilience of inner-city youth. Adolescence, 35, 717-730.

Damon, W., \& Lerner, R. M. (2008). Child and adolescent development: An advanced course.

Donahue, M. J.: 1985, 'Intrinsic and Extrinsic Religiousness: Review and Meta-Analysis', Journal of Personality and Social Psychology. 48(2), 400-419.

Erickson, E. H. (1965). The challenge of youth. New York: W. W. Norton.

Erikson, E. H. (1968). Identity: Youth and crisis. New York: W. W. Norton.

Farhan, F., \& Rofi'ulmuiz, M. A. (2021). Religiosity and Emotional Intelligence on Muslim Student Learning Achievement. International Journal of Evaluation and Research in Education, 10(2), 404-411.

Fatima, S. M. Mehfooz, and S. Sharif, 2017. "Role of Islamic religiosity in predicting academic motivation of university students,” Psycholog. Relig. Spiritual., vol. 9, no. 4, pp. 377-386.

Hamza Kraim. (2010). Measuring Religiosity in consumer research from Islamic perspective.

Jessor, R. J., Turbin, M. S., \& Costa, F. M. (1998). Risk and protection in successful outcomes among disadvantaged adolescents. Applied Developmental Science, 2, 194-208.

Johnstone, R.L. (1975). Religion and society in interaction: The sociology of religion. Englewood Cliffs, NJ: Prentice-Hall.

Jung, C. G. (2020). Psychology and the East. Princeton University Press.

Lapsley, D. K. \& Narvaez, D. (2006) Character education. in: K. A. Renninger \& I. E. Sigel (Eds.) Handbook of child psychology: Child psychology in practice (Vol. 4, pp. 248-297). New York, NY: J. Wiley \& Sons.

Łowicki, P., \& Zajenkowski, M. (2020). Empathy and exposure to credible religious acts during childhood independently predict religiosity. The International Journal for the Psychology of Religion, 30(2), 128-141.

Merriam, S. B., \& Tisdell, E. J. (2015). Qualitative research: A guide to design and implementation.

Niazi, M. A. K., Ghani, U., \& Aziz, S. (2019). Impact of Islamic Religiosity on Consumers' Attitudes towards Islamic and Conventional ways of Advertisements, Attitude towards Brands and Purchase Intentions. Business and Economic Review, 11(1), 1-29.

Olufadi, Y. (2017). Muslim Daily Religiosity Assessment Scale (MUDRAS): A new instrument for Muslim religiosity research and practice. Psychology of Religion and Spirituality, 9(2), 165.

Peterson, C., \& Seligman, M. E. (2004). Character strengths and virtues: A handbook and classification (Vol. 1). Oxford University Press.

Pratono, A. H. (2019). Linking religiosity to citizenship behaviour under materialism attitude: Empirical evidence from Indonesia. International Journal of Ethics and Systems.

"Sahih al-Bukhari, Vol. 6, Book 6o, Number 300, lạdīth 47." [Online]. Available: https://sahihbukhari.com/Pages/Bukhari_6_60.php (accessed Oct. 19, 2020).

Seligman, M. E. P. (2002). Authentic happiness. New York: Free Press.

Shubert, J. (2018). Developmental change in character strengths across childhood and adolescence and 
in school contexts. University of Rochester.

Stark, R., \& Glock, C. Y. (1965). The" New Denominationalism". Review of religious research, 7(1), 8-17.

Ullah, K., Haider, S., \& Hameed, G. (2021). Examining Islamic Religiosity and Youth Perception towards Socio-Economic and Cultural Impact of Tourism Development in Gilgit-Baltistan, Pakistan.

Weaver, G.R. and Angel, B.R. (2002), Religiosity and ethical behavior in organizations: a symbolic interactionalist perspective, Academy of Management Review, 27(1), 77-97.

Yahya, K. K., Yean, T. F., Johari, J., \& Saad, N. A. (2015). The perception of gen Y on organizational culture, religiosity and corruption in Malaysian public organizations. Procedia Economics and Finance, 31, 251-261.

Zamani-Farahani, H., \& Musa, G. (2012). The relationship between Islamic religiosity and residents' perceptions of socio-cultural impacts of tourism in Iran: Case studies of Sare' in and Masooleh. Tourism management, 33(4), 802-814.

Zuckerman, M., Silberman, J., \& Hall, J. A. (2013). The relation between intelligence and religiosity: A meta-analysis and some proposed explanations. Personality and social psychology review, 17(4), 325-354. 